UDC 615

doi: https://doi.org/10.15407/ubj90.04.045

\title{
GENTAMICIN AND MAGNESIUM CHLORIDE NORMALIZES CHOLINESTERASE AND ATPaSe ACTIVITIES IN RATS ACUTELY EXPOSED TO DICHLORVOS (DDVP) PESTICIDE
}

\author{
B. S. AJILORE ${ }^{1 凶}$, A. E. ADEWUYI', T. O. OLUWADAIRO² \\ ${ }^{1}$ Department of Biochemistry, Faculty of Basic Medical Sciences, \\ College of Health Sciences, Osun State University, Osogbo, Nigeria; \\ 凶e-mail: doctorajibam@yahoo.com; \\ ${ }^{2}$ Department of Chemical Sciences, Faculty of Basic and Applied Sciences, \\ College of Science, Engineering and Technology, Osun State University, Osogbo, Nigeria
}

This study investigated possible use of gentamicin and magnesium chloride as antidotes of dichlorvos pesticide poisoning. Thirty albino rats were randomly divided into 5 groups $(n=6)$. Group 1 served as negative control and received distilled water only. Group 2 served as positive control and was treated with $2.5 \mathrm{mg} / \mathrm{kg}$ body weight dichlorvos intraperitoneally. Group 3 was post-treated with $0.5 \mathrm{mg}$ atropine following intraperitoneal $2.5 \mathrm{mg} / \mathrm{kg}$ dichlorvos while groups 4 and 5 were post-treated with $28 \mathrm{mg} / \mathrm{kg}$ intramuscular magnesium chloride and $5 \mathrm{mg} / \mathrm{kg}$ intramuscular gentamicin respectively following intraperitoneal $2.5 \mathrm{mg} /$ $\mathrm{kg}$ dichlorvos. Plasma and red blood cell acetylcholinesterase activities were estimated. Total ATPase, $\mathrm{Na}^{+} /$ $\mathrm{K}^{+}$-ATPase, $\mathrm{Ca}^{2+}$-ATPase, and $\mathrm{Mg}^{2+}$-ATPase activities were estimated in the brain. Results showed significant $(P<0.05)$ increase in acetylcholinesterase activities in rats post treated with atropine, $\mathrm{MgCl}_{2}$ and gentamicin when compared with acetylcholinesterase activities in rats treated with dichlorvos only. There is significant $(\mathrm{P}<0.05)$ increase in the activities of $\mathrm{Ca}^{2+}, \mathrm{Mg}^{2+}$-ATPases, $\mathrm{Na}^{+} / \mathrm{K}^{+}$-ATPase and total ATPase activities in the brain of rats post treated with atropine, magnesium chloride and gentamicin. Dichlorvos significantly $(P<0.05)$ reduced plasma and red blood cell cholinesterase activities, and brain ATPases activities. We concluded that dichlorvos toxicity inhibited cholinesterase, $\mathrm{Na}^{+} / \mathrm{K}^{+}$-ATPase and $\mathrm{Ca}^{2+}, \mathrm{Mg}^{2+}$-ATPases activities. Magnesium chloride and gentamicin on the other hand reduced effects of dichlorvos poisoning by promoting normal ATPase activities and inhibiting release of acetylcholine from cell. We proposed that both magnesium chloride and gentamicin can be co-administered in future as antidotes to patients with dichlorvos poisoning.

Ke y wo rd s: dichlorvos (DDVP), gentamicin, magnesium chloride, acetylcholinesterase, ATPases P-type.

$\mathrm{D}$ ichlorvos (2, 2-dichlorovinyldimethylphosphate, DDVP) belongs to a class of pesticides referred to as organophosphates. It is used to control household and farm pests like mushroom flies, aphids, spider mites, caterpillars, thrips, and white flies [1]. DDVP is marketed as an aerosol and soluble concentrate. Organophosphorus pesticide poisoning is a serious public health concern in developing countries [2] with Nigeria inclusive. Self-poisoning with DDVP pesticide is an important public health concern. Every year, about one million unintentional and two million self poisonings with pesticides occur worldwide, and of these, approximately 200, 000 die [3, 4]. Symptoms and signs of
DDVP poisoning include nausea, vomiting, diarrhea, abdominal cramps, headache, dizziness, eye pain, blurred vision, constriction or dilation of the eye pupils, tears, salivation, sweating, and confusion. Severe DDVP poisoning causes slurred speech, loss of reflexes, weakness, fatigue, involuntary muscle contractions, twitching, tremors of the tongue or eyelids, and eventually paralysis of the body extremities and the respiratory muscles [3]. Though atropine and oxime are the main antidotes of organophosphorous poisoning worldwide, but their efficacies have been an issue of debate [4]. Studies to find more effective antidotes for organophosphorus poisoning are in progress.

(C) 2018 Ajilore B. S. et al. This is an open-access article distributed under the terms of the Creative Commons Attribution License, which permits unrestricted use, distribution, and reproduction in any medium, provided the original author and source are credited. 
Dichlorvos strongly binds to acetyl cholinesterase (AChE) molecules to form AChE-OP complex. This phosphorylation causes inactivation of the enzyme [5], accumulation of acetylcholine and subsequent over-activation of cholinergic receptors [6]. Reactivation of AChE can be hastened by nucleophilic reagents [7]. The main toxic action of organophosphorus is as a result of inhibition of the active site of acetylcholinesterase, but some organophosphorus esters can cause a neuropathic anomaly which is not related to acute cholinergic effect [8] but due to interaction of organophosphorus insecticides with activities of membrane ATPases. Nozdrenko et al. [9] reported that chlorpyrifos inhibited $\mathrm{Ca}^{2+}, \mathrm{Mg}^{2+}-$ ATPase activity of sarcoplasmic reticulum of skeletal muscle.

The chemistry of magnesium cation in hydrolysis reactions like phosphate ester hydrolysis and phosphoryl transfer [10,11], and unwanted effect of gentamicin, an aminoglycoside, as presynaptic neuromuscular blockade inhibiting calcium influx required for exocytosis [12]. The aim of the present study was to investigate the possible benefits of magnesium chloride and gentamicin in organophosphorus poisoning targeting their abilities to interact with substrates and membrane enzymes.

\section{Materials and Methods}

Chemicals and reagents. Adenosine triphosphate and acetylcholine iodide were obtained from Sigma Chemical Company. DDVP was purchased from Forward (Beihaj) Hepu Pesticide Co. Ltd., Guangx, China. Sodium barbital, potassium dihydrogen phosphate, sodium chloride, Tris, EDTA, magnesium chloride, potassium chloride, calcium chloride, ammonium molybdate, aminonaphthol sulfonic acid (ANSA), trichloroacetic acid (TCA), 5,5'-dithiobis-2-nitrobenzoic acid (DTNB) were either obtained from BDH Ltd. Poole, England or Scharlab S.L. Spain. All reagents and chemicals used were of analytical grade.

Grouping and treatment of experimental animals. Experimental animals were used in accordance with the European Convention for the protection of vertebrate animals used for experimental and other scientific purposes. Thirty albino rats were kept in clean plastic cages and fed with rat feeds and water ad libitum. The rats were randomly divided into five groups $(n=6)$ following two weeks acclimatization. Group 1 served as negative control and received distilled water only. Group 2 served as posi- tive control and was treated with single dose $2.5 \mathrm{mg} /$ $\mathrm{kg}$ body weight dichlorvos intraperitoneally. Group 3 was treated daily with $0.5 \mathrm{mg}$ intramuscular atropine for 7 days following intraperitoneal $2.5 \mathrm{mg} / \mathrm{kg}$ body weight dichlorvos while groups 4 and 5 rats were treated daily with $28 \mathrm{mg} / \mathrm{kg}$ body weight intramuscular magnesium chloride and $5 \mathrm{mg} / \mathrm{kg}$ body weight intramuscular gentamicin respectively for 7 days following intraperitoneal $2.5 \mathrm{mg} / \mathrm{kg}$ body weight dichlorvos. All the rats were sacrificed at the end of 1 week of treatment. Blood samples were collected by ocular puncture before sacrificing the animals and brain tissues was harvested.

Blood sample preparation. Plasma was obtained after centrifuging $4 \mathrm{ml}$ of blood sample at $3,000 \mathrm{~g}$ for $10 \mathrm{~min}$. Red blood cells were washed 3 times with $2 \mathrm{ml}$ sodium phosphate buffer $(0.1 \mathrm{M}$, $\mathrm{pH}$ 8). The red blood cells were centrifuged between washes at $3,000 \mathrm{~g}$ for $10 \mathrm{~min}$. Packed red blood cells were then diluted by hypotonic sodium phosphate buffer (6.7 mM, pH 7.9) to facilitate hemolysis. This was followed by centrifugation at 3,000 $\mathrm{g}$ for $10 \mathrm{~min}$. The supernatant was removed and pellet was resuspended in hypotonic phosphate buffer. The plasma and blood cell ghosts were used to determine total acetylcholinesterase activity.

Preparation of brain homogenate. Brain tissue harvested from each rat was weighed and homogenized in sodium phosphate buffer (tissue: buffer/1:10), centrifuged at $9,000 \mathrm{~g}$ for $5 \mathrm{~min}$ at $4{ }^{\circ} \mathrm{C}$ and supernatant obtained was used for estimation of ATPase activities.

Determination of cholinesterase activity. Plasma and erythrocyte acetylcholinesterase activities were estimated using method described by Ellman et al. [13] with little modifications. Acetylcholinesterase activity was calculated using an extinction coefficient of $13.6 \mathrm{mM}^{-1} \mathrm{~cm}^{-1}$ for 5,5'-dithiobis-2-nitrobenzoic acid (DTNB) and expressed as $\mathrm{nmol} / \mathrm{min} / \mathrm{ml}$. 1 unit $=1 \mu \mathrm{mol}=1000 \mathrm{nmol}$.

$$
\text { AChE Activity }=\left(\Delta \mathrm{E} \times V_{\mathrm{f}}\right) /\left(\Delta \mathrm{t} \times \Sigma \times V_{\mathrm{s}} \times \mathrm{d}\right) \text {, }
$$
where, $\Delta \mathrm{E}$ - change in $\mathrm{OD}$ at $410 \mathrm{~nm} ; V_{\mathrm{f}}-$ final volume of the assay mixture; $\Delta \mathrm{t}$ - time of hydrolysis/ incubation; $\Sigma$ - Extinction coefficient; $V_{s}$ - volume of DTNB in the assay mixture; $\mathrm{d}$ - diameter of cuvette used.

Determination of ATPase activities. Total ATPase activity in brain homogenate was measured by the method of Evans [14] with few modifications. Briefly, $0.1 \mathrm{ml}$ of sample was added to test tube containing $0.1 \mathrm{ml}$ each of $0.1 \mathrm{mM}$ Tris-HCl ( $\mathrm{pH}$ 7.4), 
$0.1 \mathrm{mM} \mathrm{NaCl}, 0.1 \mathrm{mM} \mathrm{MgCl}, 1.5 \mathrm{mM} \mathrm{KCl}, 0.1 \mathrm{mM}$ EDTA and $0.1 \mathrm{mM}$ ATP. The mixture was incubated at $37{ }^{\circ} \mathrm{C}$ for $20 \mathrm{~min}$. The reaction was arrested after $20 \mathrm{~min}$ by the addition of $9 \mathrm{ml}$ of 5\% TCA and then centrifuged at $1500 \mathrm{~g}$ for $10 \mathrm{~min}$. The liberated inorganic phosphorus $\left(\mathrm{P}_{\mathrm{i}}\right)$ was estimated in the protein free supernatant at $680 \mathrm{~nm}$ [15]. The activity of $\mathrm{Na}^{+} / \mathrm{K}^{+}$-dependent ATPase was determined by the method of Bonting [16]. The activity of $\mathrm{Ca}^{2+}$-ATPase was assayed according to the method of Hjertan and Pan [17]. The activity of $\mathrm{Mg}^{2+}$-ATPase was assayed by the method of Ohinishi et al. [18].

Statistical analysis. Data obtained were analyzed using One Way Analysis of Variance (SPSS version 20.0). Levene statistic was used for tests of homogeneity of variance. Duncan was used for multiple comparisons and homogenous subsets. Results were considered to be statistically significant with $P<0.05$.

\section{Results and Discussion}

The results of our study showed that single dose of intraperitoneal $2.5 \mathrm{mg} / \mathrm{kg}$ dichlorvos (DDVP) significantly $(P<0.05)$ reduced cholinesterase activities in plasma and on red blood cell when compared with respective normal values in plasma and on red blood cell; and treatments with atropine, magnesium chloride and gentamicin significantly $(P<0.05)$ increased cholinesterase activities to near normal levels. The percentage cholinesterase inhibitions in DDVP only, DDVP + atropine, DDVP + magnesium chloride and DDVP + gentamicin are 43, 16, 25 and $22 \%$ in plasma and $16,9,10$ and $11 \%$ on red blood cell respectively (Fig. 1, B and 2, B). Organophosphates are very toxic and cause acute poisoning more often than other classes of pesticides [19]. Dichlorvos is being used to control pests on the farms and in the house [20]. Self-poisoning from organophosphate pesticide use is an important clinical problem in developing world [5]. Atropine and oximes, the common antidotes being used in managing organophosphate insecticide poisoning, are not effective in some cases [7]. Organophosphorus insecticides inhibit ChE by nucleophilic attack on the active site of the enzyme [7]. Magnesium is a divalent metal which lowers pKa of nucleophiles [11] in solution, and produces charge repulsion between phosphoryl moiety of organophospate and serine-OH group of ChE, increased hydrolysis of acetycholine, reactivation of the enzyme, significant $(P<0.05)$ increase in the activities and subsequent reduction in percentage inhibition of plasma and red blood cell ChE as observed in this study.

ATPases are groups of membrane-bound enzymes involved in the breaking down of ATP to ADP and free $\mathrm{P}_{\mathrm{i}}$. The dephosphrylation is coupled with release of energy needed by the enzyme to drive endergonic reactions. Inhibition of ATPase activities could be an index of toxicity from environmental contaminants [21]. Fig. 3 showed total ATPase, $\mathrm{Na}^{+} / \mathrm{K}^{+}$-ATPase, $\mathrm{Ca}^{2+}$-ATPase and $\mathrm{Mg}^{2+}$-ATPase activities in all the treatment groups. Intraperitoneal $2.5 \mathrm{mg} / \mathrm{kg}$ bwt DDVP significantly $(P<0.05)$ reduced brain ATPases levels while treatments with atropine, magnesium chloride and gentamiicin significantly $(P<0.05)$ raised brain ATPases to near
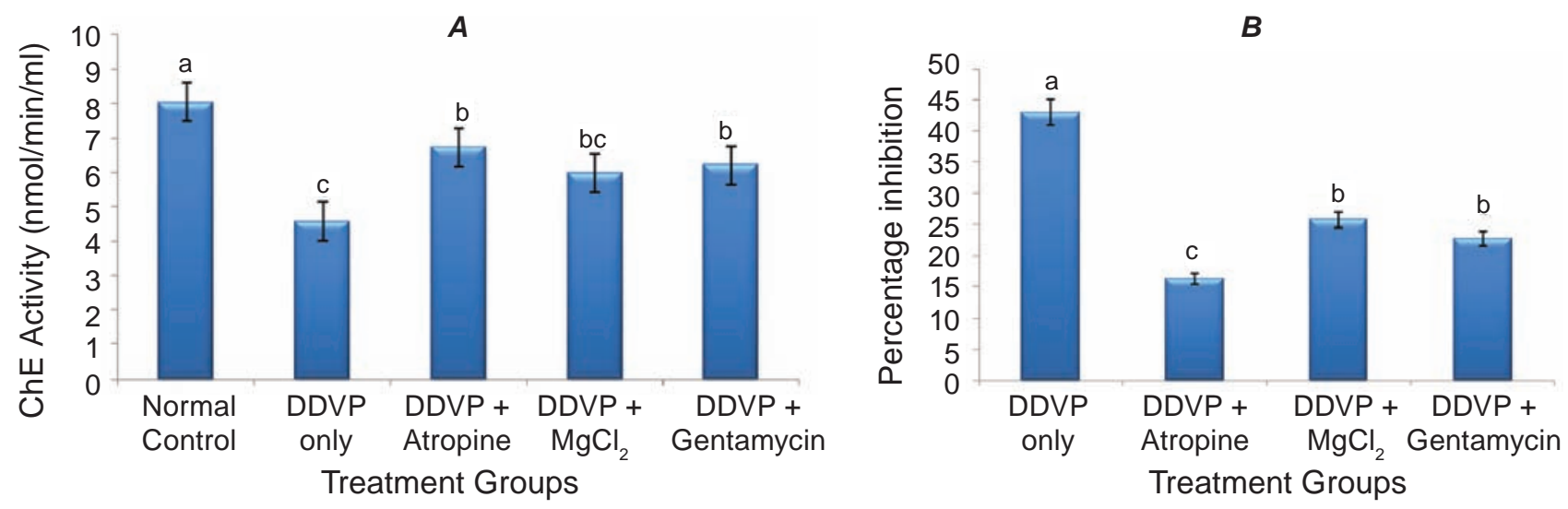

Fig. 1. Effects of atropine, magnesium chloride and gentamicin on DDVP inhibition of plasma cholinesterase activity (A) and percentage inhibition of plasma cholinesterase by DDVP (B). Values are expressed as mean $\pm S D(n=6)$. Duncan superscripts $\boldsymbol{a}, \boldsymbol{b}, \boldsymbol{b} \boldsymbol{c}, \boldsymbol{c}$ are significance homogenous subsets of means within groups. Bars with different Duncan superscripts are statistically significant at $P<0.05$ 

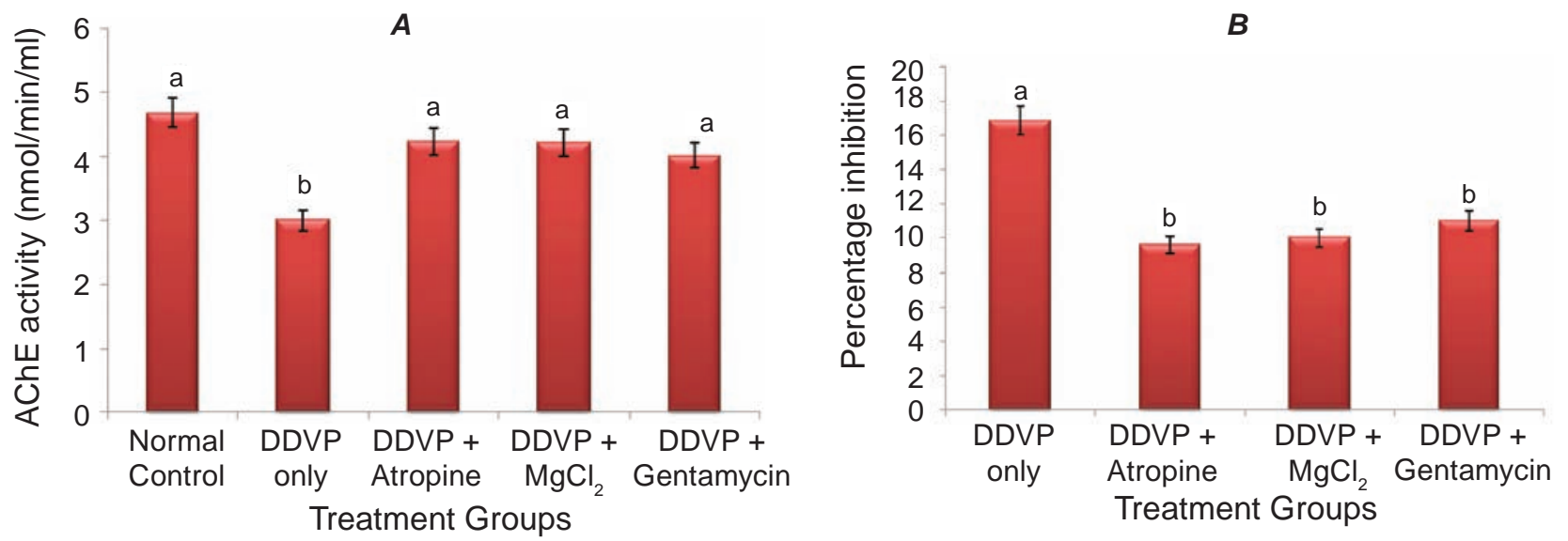

Fig. 2. Effects of atropine, magnesium chloride and gentamicin on DDVP inhibition of red blood cell acetylcholinesterase activity (A) and percentage inhibition of red blood cell acetylcholinesterase by DDVP (B). Values are expressed as mean $\pm S D(n=6)$. Duncan superscripts $\boldsymbol{a}, \boldsymbol{b}$ are significance homogenous subsets of means within groups. Bars with different Duncan superscripts are statistically significant at $P<0.05$

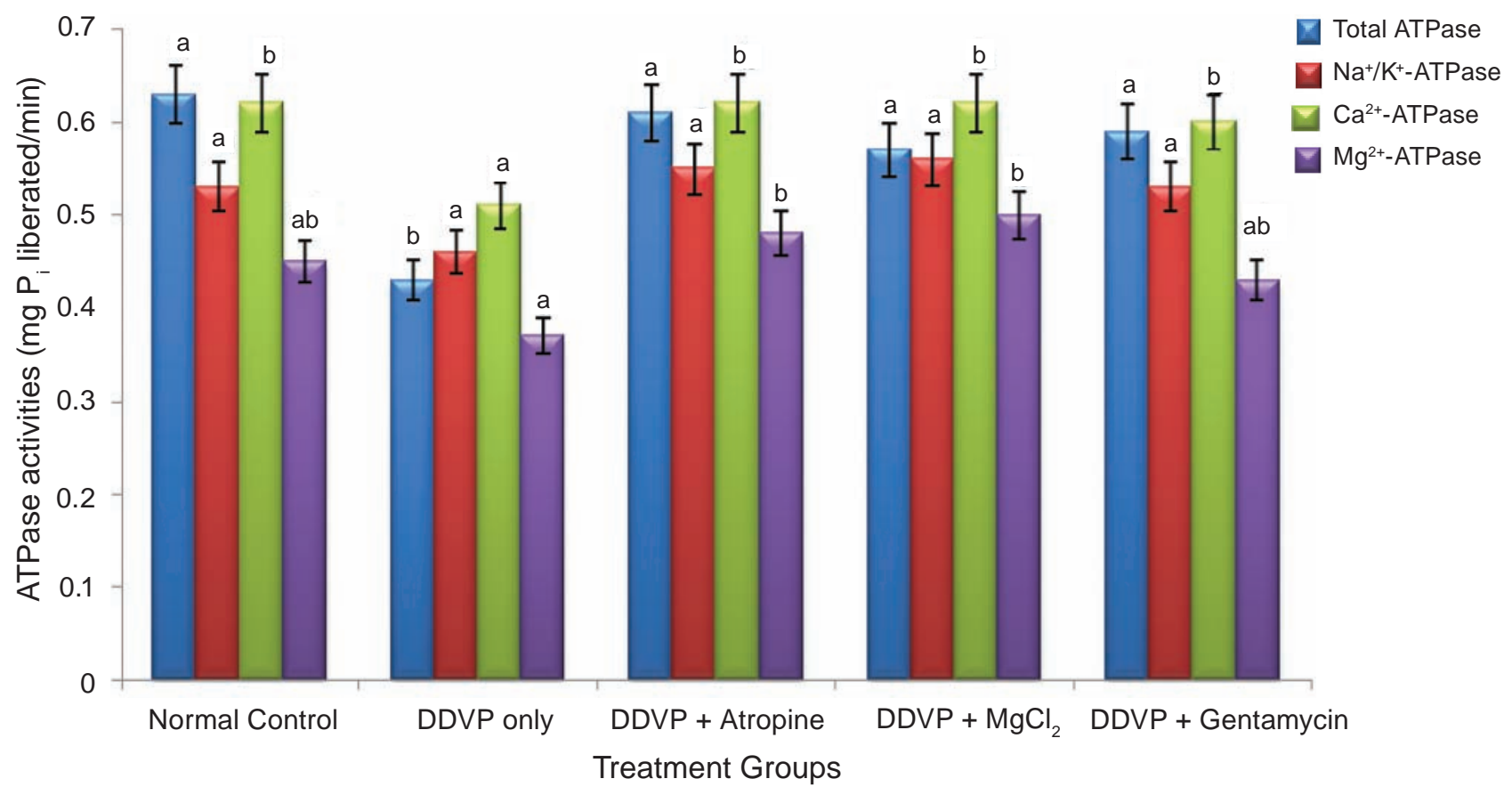

Fig. 3. Effects of atropine, magnesium chloride and gentamicin on brain ATPase levels. Values are expressed as mean $\pm S D(n=6)$. Duncan superscripts $\boldsymbol{a}, \boldsymbol{a b}, \boldsymbol{b}$ are significance homogenous subsets of means within groups. Bars of the same legend with different Duncan superscripts are statistically significant at $P<0.05$

normal levels. ATPase is a specific feature of the interior part of $\mathrm{Na}^{+}-\mathrm{K}^{+}$pump, a carrier membrane protein that pumps sodium ions outward through the cell membrane of all cells and at the same time pumps potassium ions from the outside to the inside. This pump is responsible for establishing a negative electrical voltage inside the cells that maintains resting membrane potential [22]. ATPase is also an important part of $\mathrm{Ca}^{2+}$ pump. Significant $(P<0.05)$ inhibition of brain $\mathrm{Na}^{+} / \mathrm{K}^{+}$-ATPase by dichlorvos insecticide in this study is responsible for increased intracellular sodium ions, membrane depolarization and muscular twitching among other signs and symptoms of organophosphorus poisoning. Calcium pump requires magnesium for normal export of calcium and keeps intracellular calcium level low [23]. 
Inhibition of this enzyme by dichlorvos causes elevated intracellular calcium [24], increased exocytosis of acetycholine, and is associated with signs and symptoms of neuropathy seen in organophosphate toxicity [25].

$\mathrm{Mg}^{2+}$ is an important co-factor in many enzymes including ATPases [26]. The significant $(P<0.05)$ increase in the activities of AChE in groups treated with gentamicin and magnesium chloride in this study may be as a result of significant $(P<0.05)$ increase in the levels $\mathrm{Ca}^{2+}, \mathrm{Mg}^{2+}$-ATPases. $\mathrm{Ca}^{2+}, \mathrm{Mg}^{2+}$-pumps decrease intracellular calcium which results in decrease in the rate of acetylcholine release from the cell (12). Therefore, significant $(P<0.05)$ inhibition of $\mathrm{Ca}^{2+}, \mathrm{Mg}^{2+}$-ATPases by dichlorvos might have resulted in increase in intracellular calcium levels, increased acetycholine release and subsequent significant $(P<0.05)$ increase in percentage inhibition of ChE observed in this study.

The results of our study concluded that dichlorvos toxicity inhibited cholinesterase, sodium/potassium ATPase and calcium/ magnesium ATPase activities. Magnesium chloride and gentamicin on the other hand mitigated effects of dichlorvos poisoning by promoting normal ATPase activities and inhibiting release of acetylcholine from cell. We proposed that both magnesium chloride and gentamicin can be co-administered in future as antidotes to patients with dichlorvos poisoning.

Conflict of interest: Authors declare no conflict of interest.

Acknowledgement and financial support: Authors received no grant for this study.

\section{ГЕНТАМІЦИН І ХЛОРИД МАГНІЮ \\ НОРМАЛІЗУЮТЬ АКТИВНІСТЬ \\ ХОЛІНЕСТЕРАЗИ І АТРазИ В \\ ЩУРІВ ЗА ВПЛИВУ ПЕСТИЦИДУ ДИХЛОФОСУ}

\author{
B. S. Ajilore ${ }^{1 \bowtie}$, A. E. Adewuyi ${ }^{2}$, \\ T. O. Oluwadairo ${ }^{2}$
}

${ }^{1}$ Department of Biochemistry, Faculty of Basic Medical Sciences,

College of Health Sciences, Osun State University, Osogbo, Nigeria;

凶e-mail: doctorajibam@yahoo.com;

${ }^{2}$ Department of Chemical Sciences, Faculty of Basic and Applied Sciences,

College of Science, Engineering and Technology,

Osun State University, Osogbo, Nigeria

У роботі вивчали можливе використання гентаміцину і хлориду магнію як антидотів у разі впливу пестициду дихлофосу. Тридцять щурів-альбіносів було розділено довільним чином на 5 груп $(n=6)$. Тварини в групі 1 (негативний контроль) отримували лише дистильовану воду. У групі 2 (позитивний контроль) тваринам вводили дихлофос у дозі 2,5 мг/кг маси тіла. У групі 3 після введення 2,5 мг/кг дихлофосу вводили 0,5 мг/кг атропіну; а в групах 4 і 5 після введення 2,5 мг/кг дихлофосу тваринам вводили 28 мг/кг хлориду магнію і 5 мг/кг гентаміцину відповідно. Визначали активність ацетилхолінестерази в плазмі крові та еритроцитах і загальну активність АТРази, $\mathrm{Na}^{+} / \mathrm{K}^{+}$АТРази, $\mathrm{Ca}^{2+}$-АТРази та $\mathrm{Mg}^{2+}$-АТРази в головному мозку. Результати показали значне $(P<0,05)$ 
збільшення активності ацетилхолінестерази в щурів після введення атропіну, $\mathrm{MgCl}_{2} \mathrm{i}$ гентаміцину порівняно зі щурами, які отримували тільки дихлофос. Також спостерігали значне $(P<0,05)$ збільшення активності $\mathrm{Ca}^{2+}, \mathrm{Mg}^{2+}-$ АТРаз, $\mathrm{Na}^{+} / \mathrm{K}^{+}$-АТРази і загальної активності АТРази в мозку щурів після введення атропіну, хлориду магнію і гентаміцину. Дихлофос значно $(P<0,05)$ знижував активність холінестерази в плазмі і еритроцитах, а також активність АТРаз в головному мозку. Зроблено висновок, що дихлофос пригнічує активність холінестерази, $\mathrm{Na}^{+} /$ $\mathrm{K}^{+}$-АТРази та $\mathrm{Ca}^{2+}, \mathrm{Mg}^{2+}$-АТРаз, тоді як хлорид магнію і гентаміцин нормалізують активність АТРаз і пригнічують вивільнення ацетилхоліну 3 клітини. На підставі одержаних резльтатів ми припускаємо, що хлорид магнію і гентаміцин можна використовувати як антидоти у разі отруєння дихлофосом.

Ключов і слова: д дихлофос (DDVP), гентаміцин, хлорид магнію, ацетилхолінестераза, АТРази Р-типу.

\section{ГЕНТАМИЦИН И ХЛОРИД МАГНИЯ НОРМАЛИЗУЮТ АКТИВНОСТЬ ХОЛИНЭСТЕРАЗЫ И АТРазЫ У КРЫС, ПОД ВОЗДЕЙСТВИЕМ ПЕСТИЦИДА ДИХЛОФОСА}

\section{B. S. Ajilore ${ }^{1 \bowtie}$, A. E. Adewuyi ${ }^{2}$, T. O. Oluwadairo ${ }^{2}$}

${ }^{1}$ Department of Biochemistry, Faculty of Basic Medical Sciences,

College of Health Sciences, Osun State University, Osogbo, Nigeria;

凶e-mail: doctorajibam@yahoo.com;

${ }^{2}$ Department of Chemical Sciences, Faculty of Basic and Applied Sciences,

College of Science, Engineering and Technology,

Osun State University, Osogbo, Nigeria

В работе изучали возможное использование гентамицина и хлорида магния как антидотов при воздействии пестицида дихлофоса. Тридцать крыс-альбиносов были разделены произвольным образом на 5 групп $(n=6)$. Животные в группе 1 (отрицательный контроль) получали только дистиллированную воду. В группе 2 (положительный контроль) животным вводили дихлофос в дозе 2,5 мг/кг массы тела. В группе 3 после введения 2,5 мг/кг дихлофоса вводили 0,5 мг/кг атропина; а в группах 4 и 5 после введения 2,5 мг/кг дихлофоса вводили 28 мг/ кг хлорида магния и 5 мг/кг гентамицина соответственно. Определяли активность ацетилхолинэстеразы в плазме крови и эритроцитах, а общую активность АТРазы, $\mathrm{Na}^{+} / \mathrm{K}^{+}$-АТРазы, $\mathrm{Ca}^{2+}$-АТРазы и $\mathrm{Mg}^{2+}$-АТРазы в головном мозгу. Результаты показали значительное $(P<0,05)$ увеличение активности ацетилхолинэстеразы у крыс после введения атропина, $\mathrm{MgCl}_{2}$ и гентамицина по сравнению с крысами, получавшими только дихлофос. Также наблюдали значительное $(P<0,05)$ увеличение активности $\mathrm{Ca}^{2+}, \mathrm{Mg}^{2+}-$ АТРа3, $\mathrm{Na}^{+} / \mathrm{K}^{+}$-АТРазы и общей активности АТРазы в мозгу крыс после введения атропина, хлорида магния и гентамицина. Дихлофос значительно $(P<0,05)$ снижал активность холинэстеразы в плазме крови и эритроцитах, а также активность АТРаз в головном мозгу. Сделан вывод, что дихлофос ингибирует активность холинэстеразы, $\mathrm{Na}^{+} / \mathrm{K}^{+}$-АТРазы и $\mathrm{Ca}^{2+}, \mathrm{Mg}^{2+}$-ATРаз, тогда как хлорид магния и гентамицин нормализуют активность АТРаз и ингибируют высвобождение ацетилхолина из клетки. На основании полученных результатов мы предполагаем, что хлорид магния и гентамицин можно использовать как антидот при отравлении дихлофосом.

Ключевы е слова: дихлофос (DDVP), гентамицин, хлорид магния, ацетилхолинэстераза, АТРазы Р-типа.

\section{References}

1. Lotti M. Clinical toxicology ofanticholinesterase agents in humans. In: Krieger R, (ed). Handbook of pesticidetoxicology. Volume 2. Agents. $2^{\text {nd }}$ ed. Academic Press; San Diego. 2001. P. 1043-1085.

2. Jeyaratnam J. Acute pesticide poisoning: a major global health problem. World Health Stat Q. 1990; 43(3): 139-144.

3. Eddleston M, Buckley NA, Eyer P, Dawson AH. Management of acute organophosphorus pesticide poisoning. Lancet. 2008; 371(9612): 597607.

4. Pajoumand A, Shadnia S, Rezaie A, Abdi M, Abdollahi M. Benefits of magnesium sulfate in the management of acute human poisoning by organophosphorus insecticides. Hum Exp Toxicol. 2004; 23(12): 565-569.

5. Shetab-Boushehri SV, Shetab-Boushehri SF, Abdollahi M. Possible role of $\mathrm{Mg}^{2+}$ ion in the reaction of organophosphate (dichlorvos) with 
serine. J Med Hypotheses Ideas. 2012; 6(1): 5357.

6. Paudyal BP. Organophosphorus poisoning. J Nepal Med Assoc. 2008; 47(172): 251-258.

7. Eddleston $\mathrm{M}$, Karalliedde L, Buckley N, Fernando R, Hutchinson G, Isbister G, Konradsen F, Murray D, Piola JC, Senanayake N, Sheriff R, Singh S, Siwach SB, Smit L. Pesticide poisoning in the developing world - a minimum pesticides list. Lancet. 2002; 360(9340): 11631167.

8. OhkawaH. Stereoselectivity of organophosphorus insecticides. In: Insecticide mode of action. (Coats J.R. ed.). New York: Academic Press. 1982. P. 163-185.

9. Nozdrenko DM, Miroshnychenko MS, Soroca VM, Korchinska LV, Zavodovskiy DO. The effect of chlorpyrifos upon ATPase activity of sarcoplasmic reticulum and biomechanics of skeleta 1 muscle contraction. Ukr Biochem J. 2016; 88(2): 82-88.

10. Herschlag D, Jencks WP. The effect of divalent metal ions on the rate and transition-state structure of phosphoryl-transfer reactions. $J$ Am Chem Soc. 1987; 109(15): 4665-4674.

11. Herschlag D, Jencks WP. Catalysis of the hydrolysis of phosphorylated pyridines by $\mathrm{Mg}(\mathrm{OH})+$ : a possible model for enzymatic phosphoryl transfer. Biochemistry. 1990; 29(21): 5172-5179.

12. Neal MJ. Medical pharmacology at a glance. 3rd edition. Blackwell Science Ltd, London. 1997; P. 18-19.

13. Ellman GL. Tissue sulfhydryl groups. Arch Biochem Biophys. 1959; 82(1): 70-77.

14. Evans DJ Jr. Membrane adenosine triphosphatase of Escherichia coli: activation by calcium ion and inhibition by monovalent cations. J Bacteriol. 1969; 100(2): 914-922.

15. Fiske $\mathrm{CH}$, Subbarow Y. The colorimetric determination of phosphorus. $J$ Biol Chem. 1925; 66: 375-400.

16. Bonting SL. Sodium-potassium activated adenosine triphosphatase and cation transport. In: Membrane and ion transport, Eds by
Bittar E.E. Wiley Inter Science, London. 1970; P. 257-263.

17. Hjertén S, Pan H. Purification and characterization of two forms of a low-affinity $\mathrm{Ca}^{2+}$ ATPase from erythrocyte membranes. Biochim Biophys Acta. 1983; 728(2): 281-288.

18. Ohnishi T, Suzuki T, Suzuki Y, Ozawa K. A comparative study of plasma membrane $\mathrm{Mg}^{2+}$-ATPase activities in normal, regenerating and malignant cells. Biochim Biophys Acta. 1982; 684(1): 67-74.

19. Mansour SA. Pesticide exposure-Egyptian scene. Toxicology. 2004; 198(1-3): 91-115.

20. Gwary OM, Hati SS, Dimari GA, Ogugbuaja VO. Pesticide Residues in Bean Samples from Northeastern Nigeria. ARPN J Sci Technol. 2012; 2(2): 79-84.

21. Yadwad VB, Kallapur VL, Basalingappa S. Inhibition of gill $\mathrm{Na}^{+} \mathrm{K}^{+}$-ATPase activity in dragonfly larva, Pantala flavesens, by endosulfan. Bull Environ Contam Toxicol. 1990; 44(4): 585-589.

22. Guyton AC, Hall JE. Textbook of medical physiology. 11th edition. Elsevier Inc. Philadelphia, PA, USA 2006.

23. Carafoli E, Stauffer T. The plasma membrane calcium pump: functional domains, regulation of the activity, and tissue specificity of isoform expression. J Neurobiol. 1994; 25(3): 312-324.

24. Barber D, Hunt J, Ehrich M. Inhibition of calcium-stimulated ATPase in the hen brain P2 synaptosomal fraction by organophosphorus esters: relevance to delayed neuropathy. $J$ Toxicol Environ Health A. 2001; 63(2): 101-113.

25. El-Fawal HA, Correll L, Gay L, Ehrich M. Protease activity in brain, nerve, and muscle of hens given neuropathy-inducing organophosphates and a calcium channel blocker. Toxicol Appl Pharmacol. 1990; 103(1): 133-142.

26. Cowan JA. Structural and catalytic chemistry of magnesium-dependent enzymes. Biometals. 2002; 15(3): 225-235.

Received 19.02.2018 